AGRO EKONOMI, Vol 31, Issue 1, June 2020, Page. x-xx

DOI : http://doi.org/10.22146/ae.55153

ISSN 0215-8787 (print), ISSN 2541-1616 (online) Available at hittps://jurnal.ugm.ac.id/iae

\title{
THE IMPACT OF CLIMATIC FACTORS ON RICE PRODUCTION IN INDONESIA
}

\author{
Aura Dhamira ${ }^{1 *}$, Irham ${ }^{2}$ \\ 1,2 Department of Agricultural Socio-Economics, Faculty of Agriculture, Universitas \\ Gadjah Mada, Yogyakarta, 55281, Indonesia \\ *Corresponding author: aura.dhamira@mail.ugm.ac.id
}

Submitted: 31 March 2020; Revised: 2 June 2020; Accepted: 20 June 2020

\begin{abstract}
Rice production is greatly affected by climatic factors which keep changing along with time. Therefore, the effects of climate change on rice production in Indonesia need to be studied. The objectives of this study are to determine: (1) the difference of interregional climate in each region and (2) the impact of climatic factors on rice production in Indonesia. Just and Pope Production function was used as the analytical frameworks, and Cobb-Douglas function form was used to analyze the data. The analysis was conducted with regards to rice production in ten provinces in Indonesia from 1985 to 2017 . The result shows that there were some differences in climatic condition in each region in Indonesia. The regression analysis shows that maximum temperature and minimum temperature have positive impacts on rice production, on the other hand, El Nino and La Nina affect the production negatively. The results of this study can be considered by the policy makers in making decisions related to adaptation and mitigation on climate change encounter.
\end{abstract}

Keywords: Climate; Production; Rice

How to cite: Dhamira, A \& Irham. 2020. The Impact of Climatic Factors on Rice Production in Indonesia. Agro Ekonomi, 31(1), x-xx

\section{INTRODUCTION}

Generally, climate change phenomenon can be seen from several signs such as the rise in global temperatures, changes in rainfall, melting of polar ice caps, extreme weather that occurs more frequently and increases sea level (Stone et al., 2010). Based on projections made by Hadi (2010), in the 2020-2070 period, surface temperatures will increase to $1^{\circ} \mathrm{C}$ relative to the base period of 1961-1990 in the regions of Java, Bali and Sumatra. Meanwhile, in Sulawesi and Nusa
Tenggara regions, the temperature is projected to increase to $0.8^{\circ} \mathrm{C}$ in the 2030s period. According to the report from World Meteorological Organization (2019), the global mean temperature for 2019 was around $1.1 \pm 0.1^{\circ} \mathrm{C}$ above the 1850-1900's baseline, and it is likely to be the second warmest on record. On the other hand, the year of 2016 remains the warmest on record.

A lot of research has been conducted on the effects of changes in climatic factors on crop production. Siddiqui et al., (2018) concluded that an 
increase in temperature can improve rice production, but a rise in temperature above a certain temperature threshold will have a bad impacton rice production. Changes in rainfall have contributed up to $6.2 \%$ for monoculture rice and do not have a significant effect on rice cultivated by intercropping in the last 50 years (Chen et al., 2014). El Nino events that occurred in 1997 and 2002 caused a decrease in production of food crops in Maluku province. Rice, which is generally cultivated in wetlands, experienced a decline in production by $2.9 \%$ during $\mathrm{El}$ Nino and an increase in production by 2.4\% when La Nina happened (Santoso 2016). On the other hand, Tan et al., (2019), in their study concluded that previous La Niña years lead to increased flooding in AW season, which decreased rice yield as much as $46 \%$ as seen in An Giang in 1985. La Niña similarly impact rice yield and profitability, although the effects are generally less severe than El Niñoyears.

Other studies show that changes in climatic factors significantly affect rice production and have different effects from one region to another. For instance, the decline in rice production in the highlands of Indonesia is lower than in the lowlands. In Java, every $1^{\circ} \mathrm{C}$ rise in temperature will reduce production by 15\% (Yuliawan \& Handoko, 2016). The authors also emphasized that insignificant decrease in production $\left(<10 \% /{ }^{\circ} \mathrm{C}\right)$ occurs in rice fields with altitude above 500 meters. It means that rice fields in the lowlands are more sensitive to temperature changes than in the highlands. An increase in annual mean temperature of $1^{\circ} \mathrm{C}$ can reduce national grain production by $1.45 \%$ (a decrease of $1.74 \%$ in northern China and a decrease of $1.19 \%$ in the southern China region). Meanwhile, an increase in rainfall annual output of 100 millimeters can increase national grain production by $1.31 \%$ (3.0\% increase in northern China and $0.59 \%$ decrease in southern China) (Holst et al., 2013). During the periods of rising temperatures, there were significant negative impacts on rice production in several regions in China, except for the Northeastern part of China, and there were significant differences for each region based on the impact of rising temperatures on rice production (Lu et al., 2019).

Similar research has been done in Indonesia, for example, Santoso (2016) conducted a study about the impact of climate change on food crops production in Maluku province. It was based on the climatological data from 1995-2012. This research focused on the effects of El Nino and La Nina on food crops production, including rice. On the other hand, Nurhayanti \& Nugroho (2015) analyzed the sensitivity of paddy's production under climate change condition in Indonesia in 1974-2015. This research used precipitation, minimum temperature, and maximum temperature as the climatic factors.

Research on the effect of climatic factors on rice production is important to be conducted due to its important role as a staple food source for Indonesian. Moreover, further updates about this subject is needed, particularly newer climatological data or different combinations of the regions and climatic factors. This research was conducted with the aim of finding out climate differences among regions, namely West 
Java, Central Java, East Java, Lampung, South Sulawesi, West Sumatra, North Sumatra, South Sumatra and West Nusa Tenggara, and the effects of climatic factors (minimum temperature, mean temperature, maximum temperature and rainfall) towards rice production in Indonesia from 1985 to 2017 . From this research, an overview of the impact of climate elements on rice production will be obtained. In addition, strategy or required actions can be formulated in response to the impacts of climatic factors on the rice production.

\section{METHODS}

\section{Data sources}

This study used secondary data such as rice production, maximum temperature, minimum temperature, mean temperature, rainfall, and Southern Oscillation Index (SOI). Rice production data was obtained from the Indonesian Ministry of Agriculture website, while climatic factors data was from BMKG website, and SOI data was obtained from the Australian Government Bureau of Meteorology. SOI was used as an indicator to determine the occurrence of El Nino and La Nina anomalies. According to Australian Government Bureau of
Meteorology, when SOI value is less than -7 , it indicates an El Nino episode, while if SOI value is more than +7 , it shows typical La Nina episodes. Regression analysis was measured by using panel data combining time series data for 33 years from 1985-2017 and cross section data from the largest rice producing provinces in Indonesia, which were West Java (combined with Banten), East Java, Central Java, Lampung, South Sulawesi, North Sumatra, West Sumatra, South Sumatra and West Nusa Tenggara. West Java and Banten provincial data were combined because Banten was a part of the West Java province before 2001.

\section{Method of analysis}

To find out the climate differences among regions, a descriptive analysis was performed. It was displayed using graphs. Climatic factors affecting rice production in Indonesia were analyzed using regression analysis derived from the Just and Pope stochastic production functions. The basic concept of this function is that the production function can be divided into two parts which are the average of the output and the variability of the output (Cabas et al., 2010; Mahmood et al., 2019).

The general form of the production function formulated by Just \& Pope (1978) is as follows:

$$
y=F(X)=f(X)+h(X) \varepsilon
$$

Where $\mathrm{y}$ is output and $\mathrm{X}$ is a set of production functions that can be used in independent variables, including climatic the Just \& Pope production function, the factors such as temperature and rainfall. Cobb-Douglas function, quadratic The parameter $\mathrm{f}(\mathrm{X})$ shows the impact of function and trans $\log$ function. In this the independent variable of the output, study, the form of the function used was while $\mathrm{h}(\mathrm{X})$ shows the impact on output the Cobb-Douglas function. The model in variability. There are three forms of this studyis:

$$
\operatorname{Ln} y_{i}^{t}=\beta_{0}+\beta_{1} \operatorname{Ln} x_{1_{i}^{t}}^{t}+\beta_{2} \operatorname{Ln} x_{2 i}^{t}+\beta_{3} \operatorname{Ln}{x_{3 i}}^{t}+\beta_{4} \operatorname{Ln}{x_{4}}_{i}^{t}+\beta_{5} D_{1}+\beta_{6} D_{2}+\varepsilon
$$


$y_{i}^{t} \quad=$ Rice production in province $i$ in year $t$ (ton)

$x_{1 i}^{t}=$ Average maximum temperature in province $i$ in year $t\left({ }^{\circ} \mathrm{C}\right)$

$x_{2 i}^{t} \quad=$ Average minimum temperature in province $i$ in year $t\left({ }^{\circ} \mathrm{C}\right)$

$x_{3 i}^{t} \quad=$ Mean temperature in province $i$ in year $t\left({ }^{\circ} \mathrm{C}\right)$

$x_{4 i}^{t} \quad=$ Average rainfall in province $i$ in year $t(\mathrm{~mm})$

$D_{1} \quad=$ Dummy El Nino (1 = El Nino, $0=$ La Nina or normal)

$D_{2} \quad=$ Dummy La Nina (1 = La Nina, 0 $=$ El Nino or normal)

$\varepsilon \quad=$ error term

The occurrence of El Nino and La Nina was determined using the Southern Oscillation Index (SOI). If the SOI score is less than -7 for more than 5 months annually, it indicates an El Nino episode, while if the index is more than +7 for more than 5 months within the same year, it indicates the occurrence of La Nina episode. When the SOI valued more than or equal to -7 and less than +7 , then it is considered as a normal year. According to International Research Institute for Climate and Society, because the SOI measurements can reflect local variability and weather disturbances, scientists usually average the readings over a 5-month period to determine whether the pressure fluctuations indicate a major event or not. The dummy variables of El Nino and La Nina were based on the occurrence of these phenomenon.

This research was conducted using panel data analysis, in which there are three estimation techniques which are Common Effect Model, Fixed Effect Model and Random Effect Model. The selection for the best model was conducted through the Chow, BreuschPagan, and Hausman Test. The Chow test was performed to compare the CEM and FEM models. If the chi-square probability value is less than the $5 \%$ confidence level, the FEM model is considered better. Meanwhile, the Breusch-Pagan test compared the CEM and REM models. If the chi-square probability is more $5 \%$, the CEM model is considered better. Moreover, the Hausman test was performed to find out which model is better between FEM and REM models, if the probability value chi-square is more than $5 \%$ confidence level, the REM model is considered better.

\section{RESULT AND DISCUSSION}

Climate differences and variations in rice production between regions in Indonesia

Based on Figure 1, the minimum temperature in the entire observation area is in the range of $22.6^{\circ} \mathrm{C}$ to $24.4^{\circ} \mathrm{C}$. The mean temperature ranges between $26.4^{\circ} \mathrm{C}-27.8^{\circ} \mathrm{C}$ where the highest temperature was experienced by East Java, and the lowest temperature occurred in West Sumatra. The 


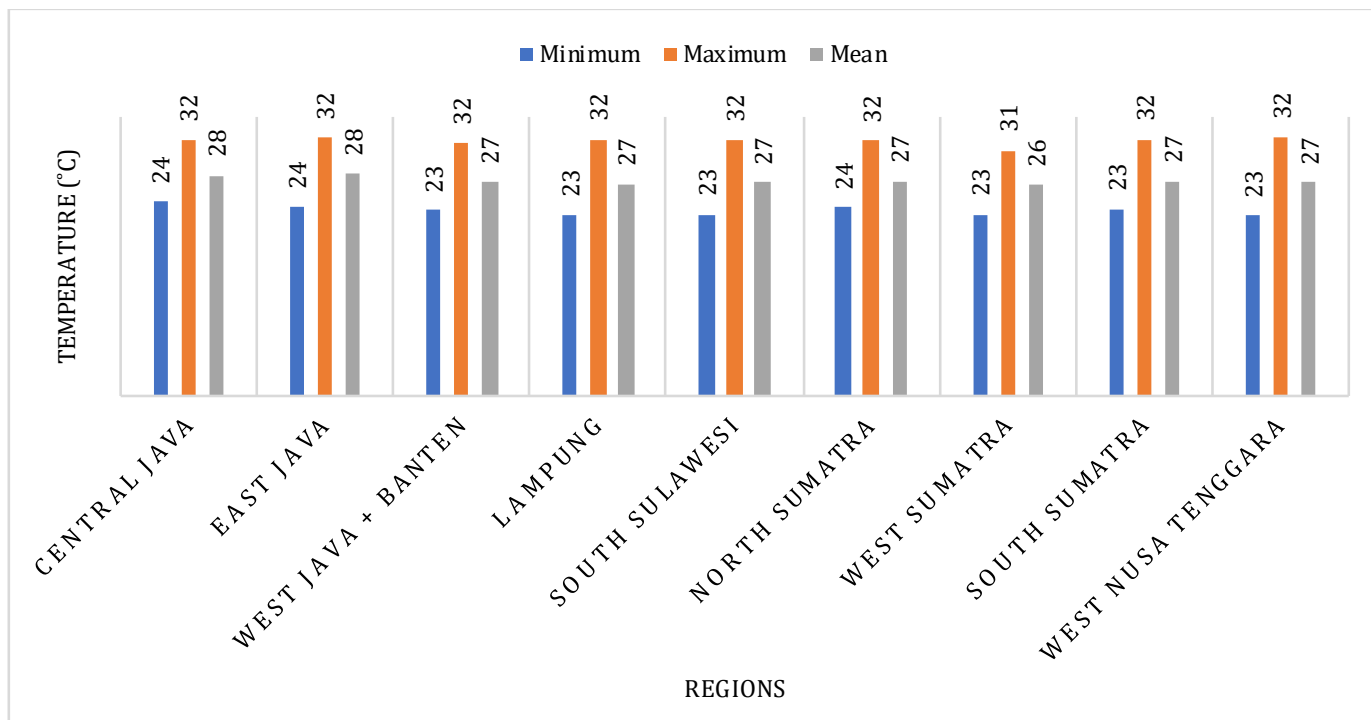

Figure 1. Temperature differences between regions in Indonesia, 1985-2017 Source: Secondary Data Analysis, 2020

maximum temperature in all provinces is in the range of $30.9^{\circ} \mathrm{C}$ to $32.4^{\circ} \mathrm{C}$.

West Sumatra Province had a relatively low temperature compared to other regions. It was caused by the topography condition of West Sumatra which is dominated by highlands. Oppositely, East Java, which is dominated by lowland areas, has a higher temperature than other regions. According to Braak's theory in Purwantara (2015), every increase in height by 100 meters above sea level, there will be a decrease in temperature of $0.6^{\circ} \mathrm{C}$. Meanwhile, according to Khandelwal et al., (2018), changes in surface temperature due to differences in height from two separate points in the horizontal direction vary between $3.5^{\circ} \mathrm{C}$ to $4.6^{\circ} \mathrm{C}$ per 1,000 meters.

Differences in climatic conditions between regions were influenced by differences in the topographic characteristics. West Java Province consists of steep mountains with an altitude of more than 1,500 meters above sea level, sloping hillside areas, and a wide plain area in the north with an altitude of 0-100 meters above sea level. Meanwhile, Central Java region comprises a variety of topographic conditions dominated by land with an altitude of 0-100 meters above sea level. There are also areas of highlands, lowlands and beaches in the northern and southern regions. Lampung Province is at an altitude between 300-500 meters above sea level, while the Province of South Sumatra is dominated by plains at an altitude of 51-100 meters above sea level. Differences in elevation between regions result in differences in climatic conditions in the region. The mean temperature in every region was 


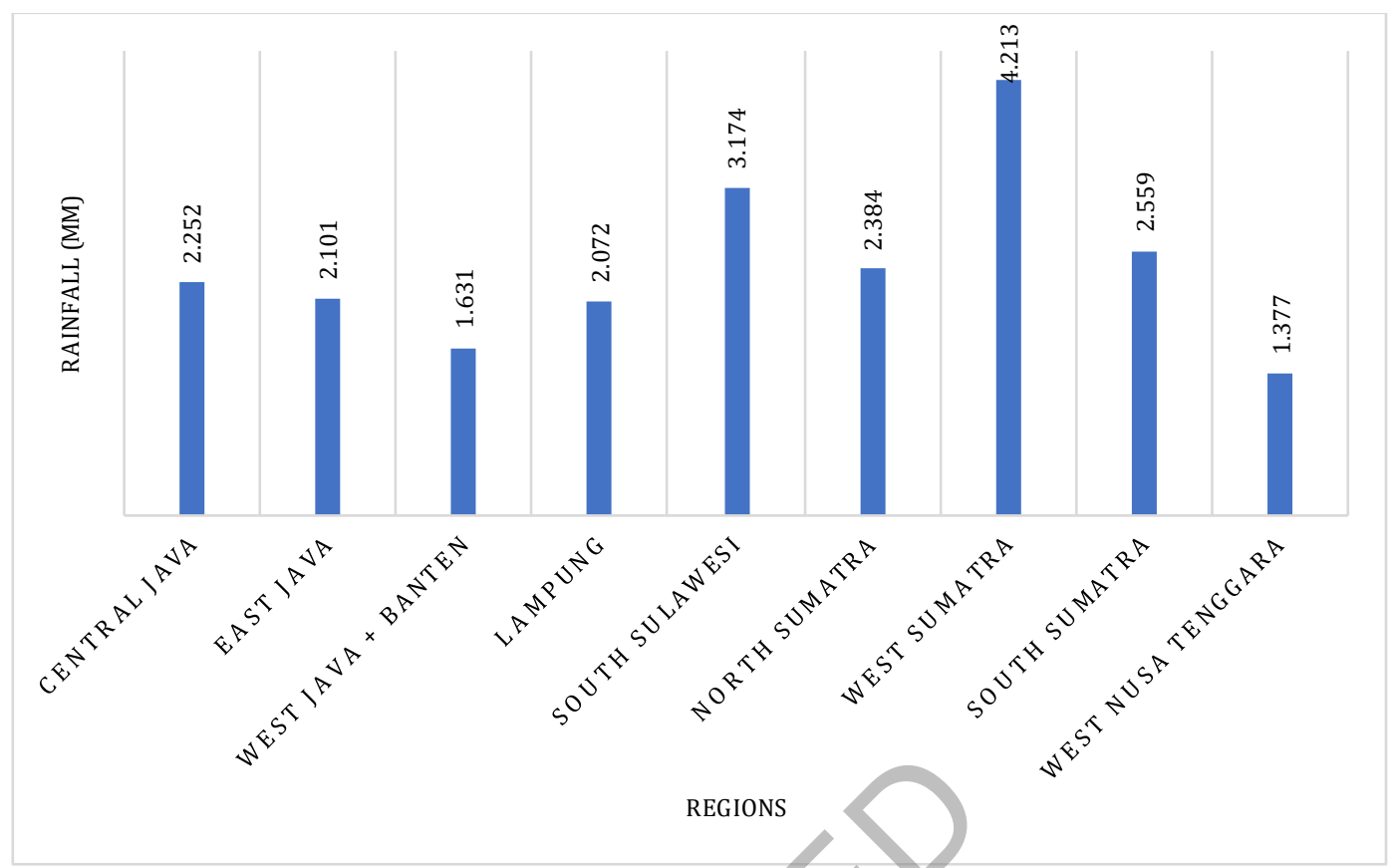

Figure 2. Rainfall differences between regions in Indonesia, 1985-2017

Source: Secondary data analysis, 2020

increasing each year with average increase rate of $0,09 \%$ per year. Most of the regions were experiencing the highest mean temperature in 2016, some of the provinces were Central Java, East Java, South Sumatra, and West Nusa Tenggara, while West Sumatra and North Sumatra were experiencing their highest temperature in 2010. The fact that most provinces had the highest mean temperature on 2016 is supported by the report by WMO stating that 2016 is the warmest year on record. West Sumatra is a province with the highest average rainfall in the last 33 years having an average rainfall of $4,212.9 \mathrm{~mm}$, followed by South Sulawesi and South Sumatra (Figure 2). The lowest average rainfall was experienced by West Nusa Tenggara which is $1,377 \mathrm{~mm}$.

West Sumatra is a province crossed by the equator. Thus, this region has higher rainfall than other regions.
Based on the general pattern of occurrence, rainfall in Indonesia can be divided into 3 types consisting of equatorial type, monsoon type and local type. Equatorial type rainfall is related to the movement of the convergence zone to the north and south following the apparent movement of the sun. The regions that follow this pattern are Sumatra and Kalimantanisland. The type of monsoon was more influenced by the presence of the winds of the west monsoon. The areas affected by this type were Java, Bali and Nusa Tenggara. Local types are influenced by local environmental conditions. The regions affected by this pattern were Papua, Maluku and parts of Sulawesi (Tukidi, 2010). Different types of rainfall emerge rainfall differences that occur between regions throughout Indonesia.

The rainfall in every region was increasing every year with the rate of 
$5,99 \%$ on average. Most of the regions experienced the lowest rainfall on 1997,

Table 1. Chow Test and Hausman Test Results

\begin{tabular}{lrc}
\hline \multicolumn{1}{c}{ Tests } & Statistics & Probability \\
\hline Chow Test & 639.873045 & 0.0000 \\
Hausman Test & 2.106546 & 0.9096 \\
Lagrange Multiplier Test & $3,051.645281$ & 0.0000 \\
\hline
\end{tabular}

Source: Secondary Data Analysis, 2020

which happened in West Sumatra, South Sulawesi, East Java, Lampung and West Java. Meanwhile South Sumatra, Central Java, and West Nusa Tenggara were experiencing the lowest rainfall on 2015. It is known that El Nino phenomenon occurred in the year of 1997 and 2015. In 1997, El Nino occurred for 10 out of 12 months and it occurred for 8 months in the year of 2015. The occurrence of El Nino in Indonesia causes a drier condition and the decrease of rainfall.

\section{Climatic factors affecting rice production}

Chow test was performed to compare between CEM and FEM. The result obtained revealed that FEM was better than CEM.

The model is indicated by the probability of chi square where the value was less than 0.05 . Then, the Hausman test was conducted to determine a better model between FEM and REM. The results show that REM was better than FEM, where the chi square probability was greater than 0.05. After that, Lagrange Multiplier test, which is conducted to compare REM and CEM revealed that REM was better than CEM, because the probability value is less than 0.05 (table 1). The results of the regression analysis of climatic factors affecting rice production using the Random Effect Model (table 2). The F test shows that all independent variables in the model affected rice production. It can be seen from the probability value which less than 0.005. Based on the results of the partial test, there were several variables that have a significant effect, including maximum temperature, minimum temperature, El Nino and La Nina.

Table 2 shows that the maximum temperature had a significant effect on rice production, where $1 \%$ raise in the maximum temperature will increase rice production by $3.76 \%$. Ghadirnezhad \& Fallah (2014) on their study said that the optimal temperature for rice growth is in the range of $25^{\circ} \mathrm{C}$ to $35^{\circ} \mathrm{C}$. Meanwhile, the average value of maximum temperature in the observed provinces ranged from $30.9^{\circ} \mathrm{C}$ to $32.4^{\circ} \mathrm{C}$, which is still included in the optimal temperature range for rice growth. Nurhayanti \& Nugroho (2015), concluded that there is a turning point on the effect of maximum temperature on rice productivity in Indonesia, where any increase in maximum temperature will increase rice productivity to a certain point, and after that, an increase in maximum temperature will reduce rice productivity. According to the estimation done this study, the turning point of 
maximum temperature was $31.35^{\circ} \mathrm{C}$. In rice plants, the extreme maximum temperature is one of important factors in the flowering phase which usually lasts for two to three weeks. However, exposure to high temperatures for several hours can reduce pollen viability resulting in loss of yield (Wassmann \& Dobermann, 2007). Maximum temperature occurred in the day-time, therefore it is related to solar radiation. According to (Yin et al., 2016), the positive impact of solar radiation is its impact on photosynthesis and net assimilation process. The average of maximum temperature in the regions ranges from $30.9^{\circ} \mathrm{C}$ to $32.4^{\circ} \mathrm{C}$, meanwhile according to Yoshida (1981), when rice plants exposed to temperatures higher than $35^{\circ} \mathrm{C}$, it will experience injury, depending on the growth stage. Based on this statement we can conclude that the maximum temperature in Indonesia has not yet reached the point that causes damage or injury which results in a decrease in production.

The minimum temperature variable has a positive effect on rice production; an increase in minimum temperature of $1 \%$ will increase rice production by $4.52 \%$ (table 2). This result was different from the results of previous studies stating that an increase in minimum temperature tends to result in a decrease in rice production (Nurhayanti \& Nugroho, 2015; Sarker et al., 2014). It is because rice planted in selected provinces is cultivated in an optimal temperature range for rice growth.

The average minimum temperature experienced by 10 rice producing provinces range from $22.6^{\circ} \mathrm{C}$ to $24.4^{\circ} \mathrm{C}$. Yoshida (1981) stated that temperature has a big influence on the growth rate of rice plants after

Table 2. Climatic factors affecting rice production

\begin{tabular}{lcccc}
\hline \multicolumn{1}{c}{ Variable } & $\begin{array}{c}\text { Expected } \\
\text { Sign }\end{array}$ & Coefficient & t-Stat & Prob. \\
\hline C & & $-22.08012^{* * *}$ & -5.781683 & 0.0000 \\
Maximum & $+/-$ & $3.764649^{* *}$ & 2.245963 & 0.0255 \\
temperature & & & 5.606409 & 0.0000 \\
Minimum & $+/-$ & $4.953989^{* * *}$ & 1.309407 & 0.1914 \\
temperature & $+/-$ & $2.821410^{\mathrm{ns}}$ & -1.401290 & 0.1622 \\
Mean temperature & - & $-0.087879^{\mathrm{ns}}$ & -2.072803 & 0.0391 \\
Rainfall & $+/-$ & $-0.061870^{* *}$ & -1.810912 & 0.0712 \\
El Nino & $+/-$ & $-0.056881^{*}$ & & \\
La Nina & & 0.384575 & & \\
\hline R-squared & & 0.371842 & & \\
Adjusted R-squared & & 0.203181 & & \\
S.E. of regression & & 30.203170 & & \\
F-statistic & & 0.000000 & & \\
Prob(F-statistic) & & & & \\
\hline
\end{tabular}

Source: Secondary Data Analysis, 2020

Description: ${ }^{* * *}$ ) Significant at 1\% (t-table: 2.59 )

${ }^{* *}$ Significant at 5\% (t-table: 1.97 ) 
*) Significant at $10 \%$ probability level, (t-table: 1.65 )

ns) not significant

germination. In the temperature range between $22^{\circ} \mathrm{C}$ to $31^{\circ} \mathrm{C}$, the growth rate increases almost linearly with an increase in temperature.

The El Nino variable had a negative influence on rice production which is its phenomenon will reduce rice production (table 2). Bhuvaneswari et al,, (2013) asserted that the El Nino episode was related to rainfall and hydrology. El Nino has an impact on decreasingrainfall. Nabilah et al., (2017) in their research concluded that in West Java region and the Java Sea, in August to September was the highest El Nino condition with an average sea surface temperature of $27.71^{\circ} \mathrm{C}$ to $27.75^{\circ} \mathrm{C}$ followed by a decrease in the intensity of rainfall, an average of 1.63-1.86 millimeters per day. The decrease in rainfall impacts on rice production because rainfall is an important climate element for rice growth. The reduced water absorbed by rice will cause rice growth suboptimal, so that production may decrease. Wu et al., (2011) examined the effects of water stress on the physiology and yields of rice production. The presence of stress in the form of lack of water after the flowering phase will cause degeneration of the spikelet. It may cause the spikelet to become sterile and the grain will be empty, resulting in the declining of rice production.

The occurrence of La Nina leads to higher rainfall in Indonesia. Based on table 2, La Nina variable has a negative impact to rice production. The occurrence of this phenomenon will decrease rice production. This result is in line with the study done by Tan et al. (2019), the result of this study shows that La Nina years lead to decrease in rice yield. Li et al., (2020) stated that the negative effect from La Nina might be caused by chill injury or frost damage, which may then cause difficulty in plant germination during crop establishment. This decrease might be caused by the possibility of flooding and increasing pests during high rainfall. It was also caused by three alternative hazards comprising of the danger of an increase in air temperature, very poor rainfall during the growing season, or a very high rainfall accompanied by flooding during the planting period which can cause reduced agricultural production (Ruminta, 2016). In December to January, the humidity and rainfall are relatively high and very suitable for the development of stem borer pests, while newly planted rice plants are very sensitive to these pests (Astriah et al., 2017). These results were consistent with previous research which stated that an increase in rainfall causesa decrease in production (Holstet al., 2013; Sarker et al., 2014).

The negative impact of changes in rainfall caused by El Nino and La Nina on rice production forced farmers and policy makers to develop strategies in dealing with this problem, one of which is the adaptation strategy. According to the study conducted by Sumaryanto (2016), the farmer's adaptive capacity vary from low to medium, meanwhile Salampessy et al., (2018) stated that rice farmers adaptive capacity was considered low and affects their adaptation level to 
climate change. The Government of Indonesia through the Ministry of Agriculture has issued regulations relating to general guidelines on climate change adaptation measures, also known as Pedum. Nevertheless, the implementation of Pedum was not easy. The challenge found in implementing climate change adaptation in the agricultural sector as well as in implementing the Pedum was the gap in the capacity of farmers and supporting infrastructure for the adaptation implementation. Inadequate availability of learning tools and the lack of knowledge of farmers made the implementation process move slowly (Perdinan et al., 2018).

On the other hand, a $1 \%$ raise in the mean temperature will increase rice production by $2.81 \%$ even though the impact was not statistically significant. This result is in line with the findings of Nurhayanti \& Nugroho (2015) stating that the raise in mean temperature is not statistically significant in rice productivity, using the linear model and non-linear model. According to table 2, the rainfall variable had a negative impact on rice production in which an increase in rainfall of $1 \%$ will result in a decrease in rice production of $0.088 \%$, but this variable was not statistically significant.

\section{CONCLUSION AND SUGGESTION}

There are differences in climatic conditions between rice producing regions in Indonesia. The mean temperature and rainfall are increasing in every region each year. Maximum temperature and minimum temperature were positively associated to rice production which means increases in maximum and minimum temperature result an increase in rice production. El Nino and La Nina had a negative impact to rice production; the presence of $\mathrm{El}$ Nino and La Nina would reduce rice production. To deal with the effects of climate change, adaptation strategies are needed to minimize the decrease of rice production, especially changes in rainfall caused by El Nino and La Nina. The regulations that have been set by the government need deeper implementation. In addition, it is also necessary to adjust the adaptation strategies for each region given the differences in climatic factors they faced.

\section{REFERENCES}

Astriah, E., Daniel, \& Prawitosari, T. (2017). Analisis Jenis dan Tingkat Serangan Hama dan Penyakit pada Tanaman Padi Menggunakan Alat Spektrometer. Jurnal AgriTechno, 1(1), 71-88. https://doi.org/10.1021/jacs.7b00 823

Bhuvaneswari, K., Geethalakshmi, V., Lakshmanan, A., Srinivasan, R., \& Sekhar, N. U. (2013). The Impact of El Niño/Southern Oscillation on Hydrology and Rice Productivity in The Cauvery Basin, India: Application of The Soil and Water Assessment Tool. Weather and Climate Extremes, 2, 39-47. https://doi.org/10.1016/j.wace.20 13.10.003

Cabas, J., Weersink, A., \& Olale, E. (2010). Crop yield response to economic, site and climatic variables. Climatic Change, 101(3), 599-616. https://doi.org/10.1007/s10584009-9754-4

Chen, C., Zhou, G. S., \& Zhou, L. (2014). 
Impacts of Climate Change on Rice Yield in China from 1961 to 2010 Based on Provincial Data. Journal of Integrative Agriculture, 13(7), 1555-1564.

https://doi.org/10.1016/S20953119(14)60816-9

Ghadirnezhad, R., \& Fallah, A. (2014). Temperature Effect on Yield And Yield Components of Different Rice Cultivars in Flowering Stage. International Journal of Agronomy, 2014.

https://doi.org/10.1155/2014/84 6707

Hadi, T. W. (2010). Scientific Basis: Analysis and Projection of Temperature and Rainfall.

Holst, R., Yu, X., \& Grün, C. (2013). Climate Change, Risk and Grain Yields in China. Journal of Integrative Agriculture, 12(7), 1279-1291. https://doi.org/10.1016/S20953119(13)60435-9

Just, R. E., \& Pope, R. D. (1978). Stochastic Specification of Production Functions and Economic Implications. Journal of Econometrics, 7(1), 67-86. https://doi.org/10.1016/03044076(78)90006-4

Khandelwal, S., Goyal, R., Kaul, N., \& Mathew, A. (2018). Assessment of Land Surface Temperature Variation Due to Change in Elevation of Area Surrounding Jaipur, India. Egyptian Journal of Remote Sensing and Space Science, 21(1), 87-94. https://doi.org/10.1016/j.ejrs.201 7.01.005

Li, Y., Strapasson, A., \& Rojas, O. (2020). Assessment of El Niño and La Niña impacts on China: Enhancing the Early Warning System on Food and Agriculture. Weather and Climate
Extremes, 27(April 2019), 100208. https://doi.org/10.1016/j.wace.20 19.100208

Lu, S., Bai, X., Li, W., \& Wang, N. (2019). Impacts of climate change on water resources and grain production. Technological Forecasting and Social Change, 143(July 2018), 76-84. https://doi.org/10.1016/j.techfore. 2019.01.015

Mahmood, N., Arshad, M., Kächele, H., Ma, H., Ullah, A., \& Müller, K. (2019). Wheat Yield Response to Input and Socioeconomic Factors Under Changing Climate: Evidence from Rainfed Environments of Pakistan. Science of the Total Environment, 688, 1275-1285. https://doi.org/10.1016/j.scitoten v.2019.06.266

Nabilah, F., Prasetyo, Y., \& Sukmono, A. (2017). Analisis pengaruh fenomena El Nino dan La Nina terhadap Curah Hujan Tahun 1998 2016 Menggunakan Indikator ONI (Oceanic Nino Index) (Studi Kasus: Provinsi Jawa Barat). Jurnal Geodesi Undip, 6(4), 402-412.

Nurhayanti, Y., \& Nugroho, M. (2015). Sensitivitas Produksi Padi terhadap Perubahan Iklim di Indonesia Tahun 1974-2015. Agro Ekonomi, 27(2), 183-196.

Perdinan, Atmaja, T., Adi, R. F., \& Estiningtyas, W. (2018). Adaptasi Perubahan Iklim dan Ketahan pangan: Telaah Inisiatif dan Kebijakan. Jurnal Hukum Lingkungan Indonesia, 5(1), 60-87.

Purwantara, S. (2015). Studi Temperatur Udara Terkini di Wilayah Jawa Tengah dan DIY. Geomedia, 13, 4152.

Ruminta, R. (2016). Analisis Penurunan Produksi Tanaman Padi Akibat 
Perubahan Iklim di KABUPATEN Bandung Jawa Barat. Kultivasi, 15(1), 37-45. https://doi.org/10.24198/kultivasi .v15i1.12006

Salampessy, Y. L. ., Lubis, D. P., Amien, I., \& Suhardjito, D. (2018). Menakar Kapasitas Adaptasi Perubahan Iklim Petani Padi Sawah (kasus Kabupaten Pasuruan Jawa Timur). Jurnal Ilmu Lingkungan, 16(1), 25. https://doi.org/10.14710/jil.16.1.2 5-34

Santoso, A. B. (2016). Pengaruh Perubahan Iklim terhadap Produksi Tanaman Pangan di Provinsi Maluku. Jurnal Penelitian Pertanian Tanaman Pangan, 35(1), 29-38. https://doi.org/10.21082/jpptp.v3 5n1.2016.p29-38

Sarker, M. A. R., Alam, K., \& Gow, J. (2014). Assessing The Effects of Climate Change on Rice Yields: An Econometric Investigation Using Bangladeshi Panel Data. Economic Analysis and Policy, 44(4), 405-416. https://doi.org/10.1016/j.eap.201 4.11.004

Siddiqui, R., Samad, G., \& Nasir, M. (2018). The impact of climate change on major agricultural crops: evidence from Punjab , Pakistan. The Pakistan Development Review, 51(4), 261276.

Stone, S., León, M. C., \& Fredericks, P. (2010). Perubahan Iklim \& Peran Hutan: Manual Komunitas. Conservation International.

Sumaryanto. (2016). Estimasi Kapasitas Adaptasi Petani Padi Terhadap Cekaman Lingkungan Usahatani Akibat Perubahan Iklim. Jurnal Agro Ekonomi, 31(2), 115. https://doi.org/10.21082/jae.v31n 2.2013.115-141
Tan, B., Id, Y., Quyen, N. H., Duong, T. H., Kham, D. Van, \& Sebastian, L. (2019). Modeling ENSO impact on rice production in the Mekong River Delta. 1-19.

Tukidi. (2010). Karakter Curah Hujan Di Indonesia. Jurnal Geografi, 7(2), 136-145. https://doi.org/10.15294/jg.v7i2.8 4

Wassmann, R., \& Dobermann, a. (2007). Climate Change Adaptation Through Rice Production in Regions With High Poverty Levels. SAT EJournal ICRISAT, 4(1), 1-24. http://www.icrisat.org/Journal/Sp ecialProject/sp8.pdf

World Meteorological Organization. (2019). WMO Statement on the State of the Global Climate in 2019 (Issue 1248).

Wu, N., Guan, Y., \& Shi, Y. (2011). Effect of Water Stress on Physiological Traits and Yield in Rice Backcross Lines After Anthesis. Energy Procedia, 5, 255-260.

https://doi.org/10.1016/j.egypro.2 011.03.045

Yin, X. G., Olesen, J. E., Wang, M., \& Öztürk, I. (2016). Climate effects on crop yields in the Northeast Farming Region of China during 1961 - 2010. https://doi.org/10.1017/S002185 9616000149

Yoshida, S. (1981). Fundamentals of Rice Crop Science. In International Rice Research Institute. https://doi.org/10.1626/pps.1.199

Yuliawan, T., \& Handoko, I. (2016). The Effect of Temperature Rise to Rice Crop Yield in Indonesia Uses Shierary Rice Model With Geographical Information System (Gis) Feature. Procedia Environmental Sciences, 33, 214- 
Agro Ekonomi Vol.31/Issue 1, June 2020

220.

016.03.072

https://doi.org/10.1016/j.proenv.2

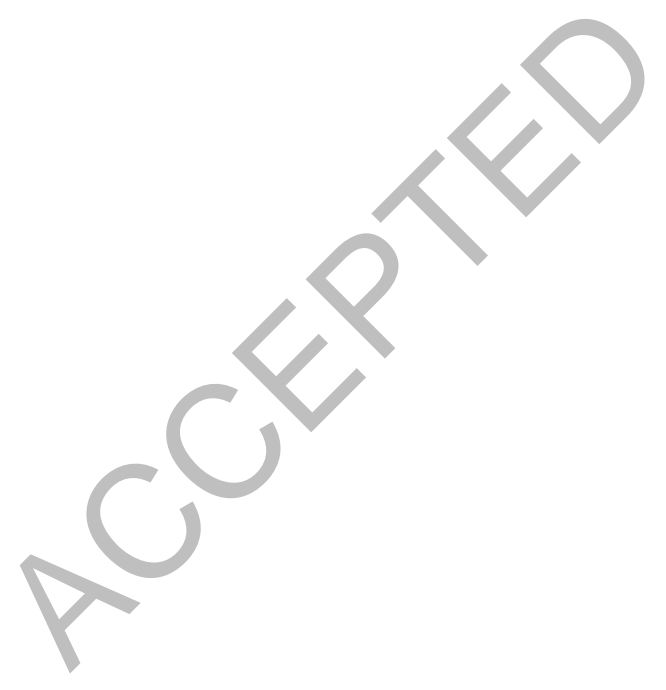

